\title{
The kinetics of antibody production to antigens of Escherichia coli 0157 in a pregnant woman with haemolytic uraemic syndrome
}

\author{
HENRIK CHART, NEIL T. PERRY, THOMAS CHEASTY and PETER A. WRIGHT* \\ Laboratory of Enteric Pathogens, Division of Gastrointestinal Infections, Central Public Health Laboratory, 61 \\ Colindale Avenue, London, NW9 5HT and * Public Health Laboratory, Royal Preston Hospital, PO Box 202, \\ Sharoe Green Lane, Fulwood, Preston, Lancs PR2 9HG
}

\begin{abstract}
Sequential blood samples taken from a pregnant woman with haemolytic uraemic syndrome caused by verocytotoxin (VT)-producing Escherichia coli 0157 were used to examine the kinetics of serum antibody production to $E$. coli 0157 lipopolysaccharide (LPS), intimin and the conserved region of the translocated intimin receptor (Tir-M). Umbilical cord blood and two samples of blood from the newborn baby were also examined for antibodies to these antigens. In the mother, antibodies of the IgM class, specific for $E$. coli 0157 LPS, were produced in the initial stages of the infection, reaching a peak at 9 days after onset of diarrhoea and subsiding 3 days later. High levels of IgG class antibodies, specific for $E$. coli 0157 LPS, were detected 8 days after the onset of diarrhoea and were present at high titres on day 18. Serum antibodies of the IgA class to $E$. coli 0157 LPS were not detected. Antibodies binding to Tir-M were detected 8 days after the onset of diarrhoea and high titres of these antibodies were still present on day 18. Serum antibodies to intimin were not detected in the mother and no antibodies to any of the antigens tested were detected in either the baby's blood or cord blood. This study describes for the first time the kinetics of serum antibody production during pregnancy, to selected antigens expressed by $E$. coli 0157 .
\end{abstract}

\section{Introduction}

Verocytotoxin-producing Escherichia coli (VTEC), and particularly strains of serotype O157:H7 and O157:H-, are a major cause of haemolytic uraemic syndrome (HUS) in the UK [1]. Patients infected with E. coli O157 produce serum antibodies to the E. coli $\mathrm{O} 157$ lipopolysaccharide (LPS) antigens [2] and these antibodies form the basis for routine serological tests, providing evidence of infection in the absence of faecal E. coli $\mathrm{O} 157$ [3]. Early studies designed to characterise the immune response to E. coli $\mathrm{O} 157$ infection detected an IgM class, but not an IgG antibody response, to E. coli O157 LPS [4], although an IgG class antibody response to E. coli O157 LPS has been reported [5]. An IgA class antibody response, to E. coli O157 LPS

Received 19 Nov. 2001; revised version accepted 15 Jan. 2002.

Corresponding author: Dr H. Chart (e-mail: hchart@phls. org.uk). was demonstrated in $76 \%$ of patients with HUS [6], and $12 \%$ of these patients produced serum antibodies of the IgA class only.

Certain strains of VTEC, including those of serogroup O157, adhere to human intestinal epithelial cells, causing 'attaching and effacing' lesions [7]. Two of the proteins involved in the adhesion process - intimin and the translocated intimin receptor (Tir) - are expressed during the pathogenesis of human disease, as indicated by the production of antibodies to intimin and the trans-membrane region of Tir (Tir-M) by patients [8].

The kinetics of antibody production by patients infected with O157 VTEC are not known; however, the Laboratory of Enteric Pathogens received sequential blood samples from a woman infected with a VTproducing strain of E. coli $\mathrm{O} 157$ during pregnancy. As a consequence, the kinetics of the serum antibody response of this patient to E. coli O157 LPS, intimin and Tir-M were examined. 


\section{Materials and methods}

\section{Patient}

A 36-year old patient was $c .30$ weeks pregnant when she experienced the onset of a severe diarrhoeal illness (designated day 1). E. coli $\mathrm{O} 157$ producing VT2 was isolated from her stool the following day (day 2) and on day 8 she developed HUS. On day 9, her baby was delivered by caesarean section. Blood samples were taken from the mother on days $4,6,8,9,10,12$ and 18 , and a sample of antenatal blood taken 5 months previously was also available. Samples of blood were also obtained from the umbilical cord (day 9), and from the baby on days 10 and 16 . Sera were prepared from these blood samples and stored at $-30^{\circ} \mathrm{C}$.

\section{Lipopolysaccharide}

For SDS-PAGE and immunoblotting, lipopolysaccharide (LPS) was prepared by digesting whole bacteria with proteinase $\mathrm{K}$ [4]. Bacteria were placed in preweighed Eppendorf tubes and the cells were suspended in SDS-PAGE sample buffer [9] to give a concentration of $1 \mathrm{mg} / 30 \mu \mathrm{l}$ before incubation at $100^{\circ} \mathrm{C}$ for $10 \mathrm{~min}$. After cooling, samples were mixed with an equal volume of SDS-PAGE buffer containing $100 \mu \mathrm{g}$ of proteinase K (Sigma) per $30 \mu \mathrm{l}$ before incubation at $60^{\circ} \mathrm{C}$ for $1 \mathrm{~h}$.

For the ELISA, LPS was prepared from outer membranes [10] by the hot-phenol method of Westphal and Jann [11]. Outer membranes were suspended in $5 \mathrm{ml}$ of de-ionised water and mixed with $5 \mathrm{ml}$ of aqueous phenol solution (Merck) $80 \%$ w/v. After incubation at $68^{\circ} \mathrm{C}$ for $15 \mathrm{~min}$, the preparation was centrifuged ( $3000 \mathrm{~g}, 30 \mathrm{~min}$, room temperature) and the aqueous phase was harvested and transferred to a clean glass container. The remaining phenol phase was mixed with $5 \mathrm{ml}$ of de-ionised water, incubated at $68^{\circ} \mathrm{C}$ for $15 \mathrm{~min}$ and centrifuged (as above). The aqueous phase was removed and mixed with the initial aqueous phase fraction before dialysis against $3 \times 5 \mathrm{~L}$ of deionised water at $4^{\circ} \mathrm{C}$. The aqueous fraction was lyophilised and the LPS was weighed. The LPS was analysed by SDS-PAGE alongside LPS prepared from whole bacteria (see above). Profiles were stained with a silver stain for carbohydrate [12] and showed that the purified LPS was representative of whole-cell LPS. They were also stained with a silver stain for protein [13] and shown not to contain contaminating cellular proteins.

\section{Tir and intimin}

Recombinant preparations of Tir-M $(24 \mathrm{kDa})$ and intimin $280_{387-666}(38 \mathrm{kDa})$ [8], were kindly donated by $\mathrm{Dr}$ Claire Jenkins, Imperial College of Science, Technology and Medicine, London.

\section{SDS-PAGE and immunoblotting}

SDS-PAGE was performed with an Atto ${ }^{\mathrm{TM}}$ mini-gel apparatus (Genetic Research Instruments, Braintree, Essex). Preparations containing $83 \mu \mathrm{g}$ of digested cell mass or $10 \mu \mathrm{g}$ of protein lane were used, loaded on to gels (stacking gel $4.5 \%$ and separating gel $12.5 \%$ ) and electrophoresis was done at $50 \mathrm{~mA}$ for $30 \mathrm{~min}$. Gels were stained either with silver to show LPS profiles [12] or with Coomassie Blue for proteins [4], or profiles were transferred on to nitrocellulose paper (NCP) by immunoblotting [4] $(0.5 \mathrm{~A}, 1 \mathrm{~h})$. Profiles immobilised on sheets of NCP were blocked with skimmed milk 3\% in phosphate-buffered saline (milkPBS) for $30 \mathrm{~min}$ and exposed to $30 \mu 1$ of serum in $5 \mathrm{ml}$ of milk-PBS for $60 \mathrm{~min}$. After washing $(3 \times 10 \mathrm{~min})$ in PBS-Tween, NCP strips were treated for $60 \mathrm{~min}$ with either goat anti-human polyvalent immunoglobulin, goat anti-human $\operatorname{IgA}$, goat anti-human $\mathrm{IgG}$, or goat anti-human IgM, all conjugated with alkaline phosphatase (and obtained from Sigma). Antibody conjugates were diluted 1 in 1000 in milk-PBS. After further washing in PBS-Tween, NCP strips were placed in substrate buffer $(0.1 \mathrm{M}$ Tris, $0.09 \mathrm{M} \mathrm{NaCl}, 0.15 \mathrm{M}$ $\mathrm{MgCl}_{2} \cdot 6 \mathrm{H}_{2} \mathrm{O}$ ) for $10 \mathrm{~min}$. For colour development, the strips were placed in $10 \mathrm{ml}$ of substrate buffer containing $45 \mu \mathrm{l}$ of nitroblue tetrazolium (Sigma), $75 \mathrm{mg} / \mathrm{ml}$ in $70 \%$ aqueous dimethyl formamide, and $35 \mu \mathrm{l}$ of 5-bromo-4-chloro-3-indolylphosphate. $\mathrm{Na}_{2}$ (Sigma), $50 \mathrm{mg} / \mathrm{ml}$ in de-ionised water.

\section{ELISA}

The ELISA [4] was done with E. coli O157 LPS and Tir-M protein. Wells were coated with $1 \mu \mathrm{g}$ of either LPS or Tir-M in $100 \mu \mathrm{l}$ of coating buffer $\left(\mathrm{Na}_{2} \mathrm{CO}_{3}\right.$ $1.59 \mathrm{~g} / \mathrm{L}$ and $\mathrm{NaHCO}_{3} 2.93 \mathrm{~g} / \mathrm{L}, \mathrm{pH}$ 9.6) and blocked with PBS containing bovine serum albumin (Sigma) $10 \mathrm{~g} / \mathrm{L}$ before the addition of patient's sera $(100 \mu \mathrm{l} /$ well). Sera were diluted 1 in 50 in PBS for detecting antibodies of the $\operatorname{IgA}$ and $\operatorname{IgG}$ classes, and 1 in 100 for antibodies of the IgM class to LPS. For identifying antibodies binding to Tir-M, sera were diluted 1 in 100 in PBS. Bound antibodies were detected with the same anti-human antibody conjugates as described for immunoblotting (above), diluted 1 in 1000 in PBS. Antibodies conjugated with alkaline phosphatase were detected by adding $200 \mu \mathrm{l}$ of diethanolamine buffer (1 $\mathrm{M}$ diethanolamine, $2 \mathrm{mM} \mathrm{MgCl} 2, \mathrm{pH} 9.6$ ) containing $p$-nitrophenyl phosphate (Sigma) $1 \mathrm{mg} / \mathrm{ml}$. The resultant colour was quantified by measuring the absorbance at $405 \mathrm{~nm}$.

\section{Results}

The seven sera prepared from the mother following infection with $E$. coli $\mathrm{O} 157$ and the sample of antenatal serum were examined for antibodies binding to E. coli O157 LPS. The SDS-PAGE profile of the LPS 
preparation, as revealed by silver staining, is shown in Fig. 1, lane 1. By immunoblotting, all seven sera prepared after the onset of disease were found to contain antibodies of the IgM class, e.g., as shown in Fig. 1, lane 2. Serum samples taken at days 8, 9, 10, 12 and 18 also contained serum antibodies of the $\mathrm{IgG}$ class to $E$. coli O157 LPS (not shown) but no antibodies of the IgA class to E. coli O157 LPS were detected. No antibodies to $E$. coli O157 LPS were detected in the antenatal blood. Serum prepared from umbilical cord blood and the two sera from the baby were also examined and did not contain antibodies of any class to E. coli O157 LPS.

The mother's IgM and IgG class serum antibody responses to $E$. coli O157 LPS were measured by ELISA, with serum dilutions in PBS of 1 in 100 and 1 in 50, respectively. As shown in Fig. 2, serum antibodies of the IgM class were detected at low titre on day $4\left(\mathrm{OD}_{405}=0.52, \sigma=0.06\right)$ which increased to a maximum on day $9\left(\mathrm{OD}_{405}=1.80, \sigma=0.19\right)$ before decreasing $\left(\mathrm{OD}_{405}=0.32, \sigma=0.03\right)$ by day 12 . In contrast, antibodies of the IgG class were detected on day $8\left(\mathrm{OD}_{405}=0.52, \sigma=0.16\right)$, reaching a peak titre on day $12\left(\mathrm{OD}_{405}=1.30, \sigma=0.18\right)$.
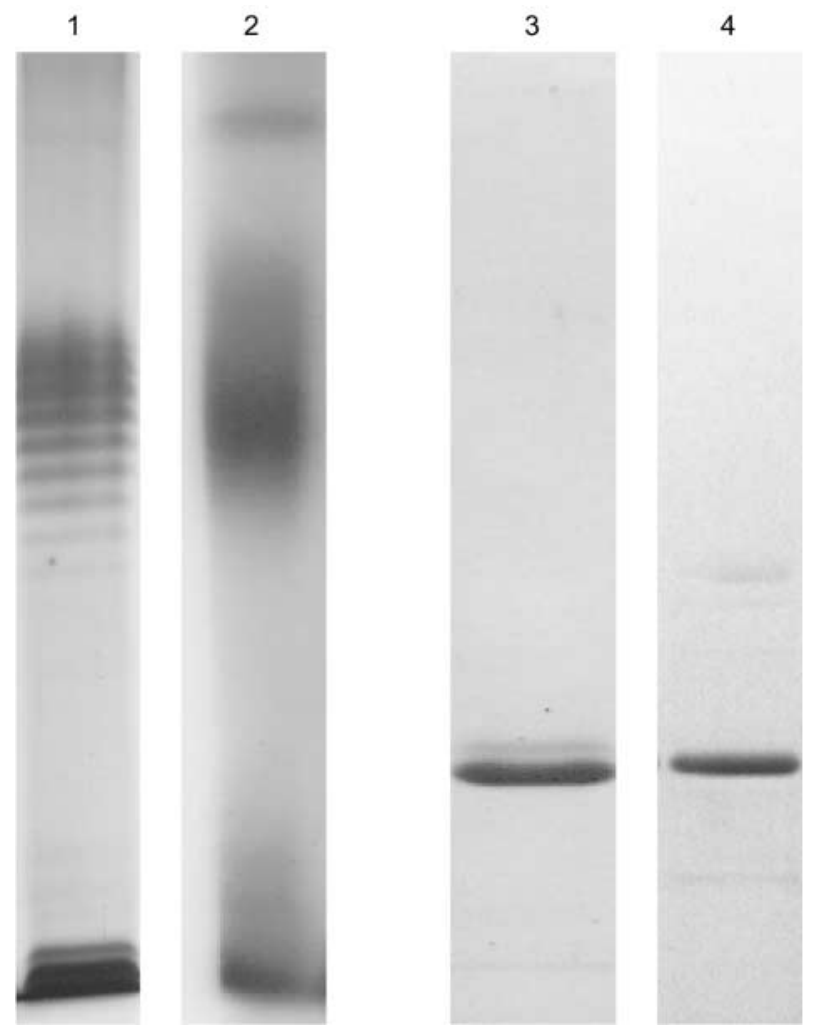

Fig. 1. SDS-PAGE and immunoblot profiles obtained with $E$. coli $\mathrm{O} 157$ antigens. Lane 1, SDS-PAGE profile of the LPS preparation as revealed by silver staining; $\mathbf{2}$, an example of an immunoblot to detect IgM antibodies to LPS in the mother's serum; 3, SDS-PAGE profile of the Tir-M preparation stained with Coomassie Blue; 4, an example of an immunoblot to detect antibodies of all classes to Tir-M.
Sera were also examined for antibodies binding to recombinant preparations of Tir-M (Fig. 1, lane 3) and intimin (not shown). By immunoblotting with an antihuman polyvalent antibody conjugate, antibodies binding to Tir-M were detected in blood samples taken on days 6, 8, 9, 10, 12 and 18, as shown in Fig. 1, lane 4, but antibodies binding to intimin were not detected in any sample. The antibody response to Tir-M was measured by ELISA (Fig. 2). A low titre of antibodies was detected in the patient's blood taken on day 6 and the titres increased to the highest level $\left(\mathrm{OD}_{405}=1.58\right.$, $\sigma=0.12$ ) on day 18 .

\section{Discussion}

Serum antibodies of the IgM class, binding to $E$. coli O157 LPS were detected early during this case study and this explains why this class of antibody forms the basis of routine serodiagnosis of infections with $E$. coli O157 [4, 14]. The titre of these antibodies declined from day 9 after the onset of diarrhoea but the reasons for this were not known. A previous study [14] suggested that $\operatorname{IgM}$ class antibody production might be variable, because certain patients had IgM class antibody titres to $E$. coli O157 LPS which declined shortly after infection whereas, for others, the titres were apparently increasing 20 days after infection.

Antibodies of the IgG class to E. coli O157 LPS appeared in the patient's blood approximately 8 days after the onset of diarrhoea and continued to persist when levels of IgM class antibodies were in decline. The fact that there have been reports of both $\operatorname{IgG}$ and IgM class antibodies to E. coli O157 LPS [5] and IgM class antibodies only [15] demonstrates that the time at which blood samples are taken can influence the class of antibodies detected. Serum antibodies of the IgA class were not detected in this patient by ELISA or immunoblotting; however, this may be because c. $24 \%$ of patients infected with $E$. coli $\mathrm{O} 157$ do not produce serum antibodies of the IgA class to E. coli O157 LPS [6]. The variation in expression of class and titre of serum antibodies observed in this study illustrates the importance of analysing patients' sera with an antihuman immunoglobulin to all three antibody classes for the routine serodiagnosis of infections with $E$. coli O157.

Serum antibodies binding to Tir-M were detected 6 days after the onset of diarrhoea, supporting other studies demonstrating serum antibodies to this protein in patients infected with E. coli O157 [8, 16]. Serum antibodies to intimin were not detected by blotting or ELISA, and the lack of an antibody response to this protein has been described elsewhere [16]. However, antibodies to intimin have been reported in other studies [8], suggesting that production of serum antibodies to this protein may be variable. Antibodies to $E$. coli $\mathrm{O} 157$ LPS were not detected in blood from 


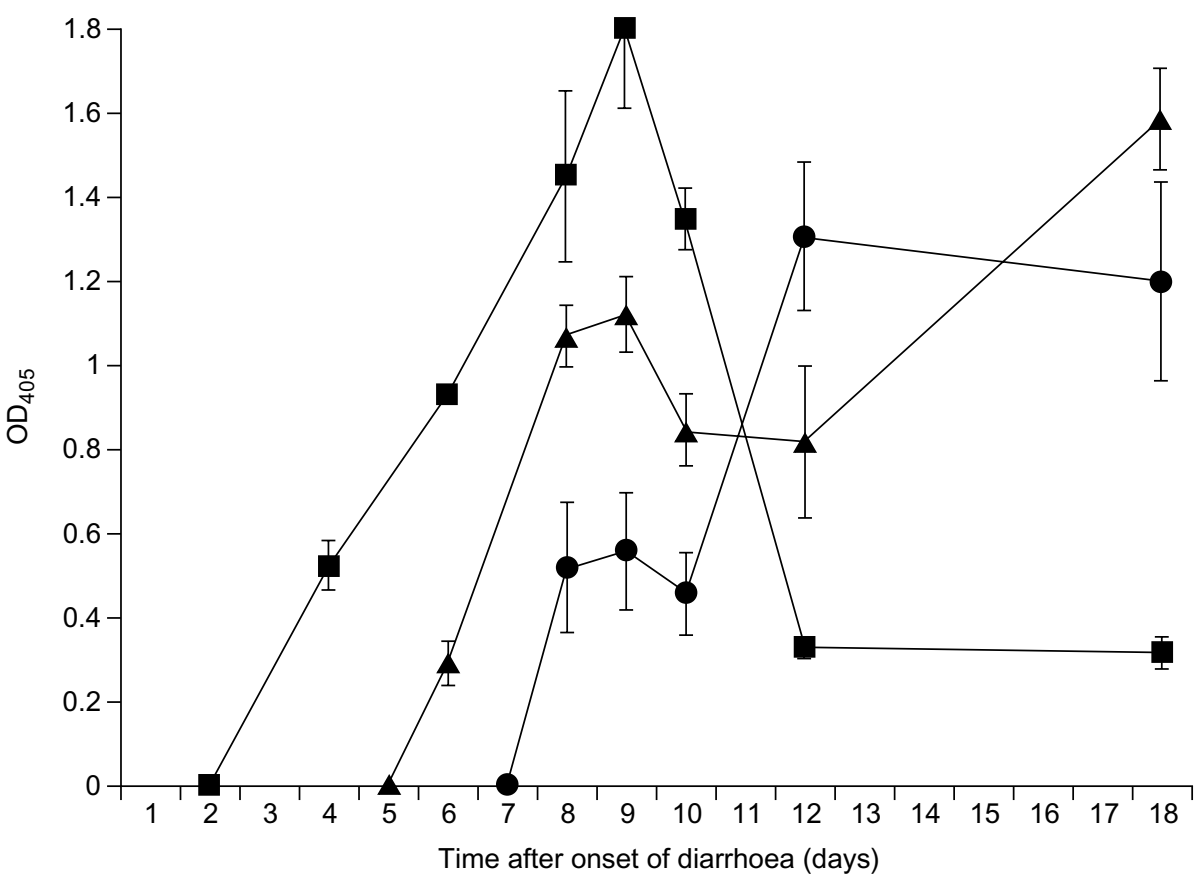

Fig. 2. The kinetics of serum antibody production to E. coli O157 LPS and Tir-M as measured by ELISA. The absorbance values indicate $\operatorname{IgM}(\boldsymbol{\square})$ and $\operatorname{IgG}(\mathbf{O})$ antibodies to LPS and polyvalent antibodies to Tir-M ( $\mathbf{\Delta})$.

the umbilical cord. As IgM class antibodies are unable to traverse the placenta, the absence of IgM class antibodies to E. coli O157 LPS was expected. However, the baby was delivered 9 days after the mother developed diarrhoea, when levels of serum IgG class antibodies to E. coli O157 LPS and Tir-M were high, and it was expected that these antibodies would be present in the baby, but for unknown reasons they were not detected.

Although a case of infection with VT-producing $E$. coli O6:H12 during pregnancy has been described previously [17], the present study is the first to examine the kinetics of serum antibody production during the pathogenesis of infection with a VT-producing strain of E. coli $\mathrm{O} 157$.

\section{References}

1. Simmons NA. Global views on Escherichia coli $\mathrm{O} 157: \mathrm{H} 7$ and other Verocytotoxic E. coli spp.: UK views. J Food Prot 1997; 60: $1463-1465$.

2. Chart H, Jenkins $\mathrm{C}$. The serodiagnosis of infections caused by Vero cytotoxin-producing Escherichia coli. J Appl Microbiol 1999; 86: 731-740.

3. Thomas A, Cheasty T, Frost JA, Chart H, Smith HR, Rowe B. Vero cytotoxin-producing Escherichia coli, particularly serogroup O157, associated with human infections in England and Wales: 1992-4. Epidemiol Infect 1996; 117: 1-10.

4. Chart H, Scotland SM, Rowe B. Serum antibodies to Escherichia coli serotype O157:H7 in patients with hemolytic uremic syndrome. J Clin Microbiol 1989; 27: 285-290.

5. Greatorex JS, Thorne GM. Humoral immune response to shiga-like toxins and Escherichia coli $\mathrm{O} 157$ lipopolysaccharide in hemolytic-uremic syndrome patients and healthy subjects.
J Clin Microbiol 1994; 32: 1172-1178.

6. Chart H, Rowe B. Improved detection of infection by Escherichia coli $\mathrm{O} 157$ in patients with haemolytic uraemic syndrome by means of IgA antibodies to lipopolysaccharide. $J$ Infect 1992; 24: 257-261.

7. Frankel G, Phillips AD, Rosenshine I, Dougan G, Kaper JB, Knutton S. Enteropathogenic and enterohaemorrhagic Escherichia coli: more subversive elements. Mol Microbiol 1998; 30 911-921.

8. Jenkins C, Chart H, Smith HR et al. Antibody response of patients infected with verocytotoxin-producing Escherichia coli to protein antigens encoded on the LEE locus. $J$ Med Microbiol 2000; 49: 97-101.

9. Laemmli UK. Cleavage of structural proteins during the assembly of the head of bacteriophage T4. Nature 1970; 227: $680-685$.

10. Chart H. Bacterial fractionation and membrane protein characterization. In: Chart $\mathrm{H}$ (ed) Methods in practical laboratory bacteriology. Boca Raton, CRC Press. 1994: 1-10.

11. Westphal O, Jann K. Bacterial lipopolysaccharides. Extraction with phenol-water and further applications of the procedure. Methods Carbohyd Chem 1965; 5: 83-91.

12. Tsai C-M, Frasch CE. A sensitive silver stain for detecting lipopolysaccharides in polyacrylamide gels. Anal Biochem 1982; 119: 115-119.

13. Wray W, Boulikas T, Wray V P, Hancock R. Silver staining of proteins in polyacrylamide gels. Anal Biochem 1981; 118: 197-203.

14. Chart H, Smith HR, Scotland SM, Rowe B, Milford DV, Taylor CM. Serological identification of Escherichia coli $\mathrm{O} 157: \mathrm{H} 7$ infection in haemolytic uraemic syndrome. Lancet 1991; 337: $138-140$.

15. Chart H, Rowe B. Failure of patients with haemolytic uraemic syndrome to produce Immunoglobulin $\mathrm{G}$ antibodies to Escherichia coli O157 lipopolysaccharide. Serodiag Immunother Infect Dis 1993; 5: 217-219.

16. Li Y, Frey E, Mackenzie AMR, Finlay BB. Human response to Escherichia coli O157:H7 infection: antibodies to secreted virulence proteins. Infect Immun 2000; 68: 5090-5095.

17. Steele BT, Goldie J, Alexopoulou I, Shimizu A. Post-partum haemolytic uraemic syndrome and Verocytotoxin-producing Escherichia coli. Lancet 1984; 1: 511. 